Survival of all fall-planted stock was equal to or better than that of spring-planted stock. This result is supported by the silvicultural recommendation by Mullin $(1968 ; 1980)$ of either spring or fall planting for black and white spruce.

Type of container had little impact on growth or survival of these species. Selection of container system would seem to be largely a matter of user logistics and preference rather than field performance.

Mullin (1980) makes a good case for use of transplant stock rather than seedlings for black and white spruce. His results tend to support those presented in this report as the 2-2 stock generally outperformed the 3-0 stock.

Comparison studies of this type must be repeated to account for variation in establishment conditions between growing seasons to provide reliable results. Additional field seasons may change the results, otherwise Mullin's recommendations remain after 15 years of growth (Mullin 1980).

\section{References}

Alm, A.A. 1975. Status of containerized forest seedling research in Minnesota. Minn. Acad. of Science Jo. 41:18-21

Mullin, R.E. 1968. Comparisons between seedlings and transplants in fall and spring plantings. Ontario Dept. Lands For. Res. Rep. $85,50 p$.

Mullin, R.E. 1980. Comparison of seedling and transplant performance following 15 years growth. For. Chron. 56(5):231-232

\title{
Genetic and Environmental Variance in Seed and Cone Characteristics of Black Spruce in a Northwestern Ontario Seed Orchard
}

by

\author{
Faye J. Verheggen ${ }^{1}$ and Robert E. Farmer, Jr. ${ }^{2}$
}

\begin{abstract}
Germination and some seed yield components were evaluated using 1981 cones from ramets of nine clones in a Northwestern Ontario seed orchard. No evidence of dormancy was observed in seed which received no chilling and were germinated under light. Hierarchical analyses of variance indicated that both clones and ramets within clones accounted for substantial amounts of variation in germination percent, filled seed percent, number of seed per cone and cone size. Cone size was only weakly correlated with number of seed per cone $(r=.44)$.
\end{abstract}

\section{Résumé}

La germination et quelques valeurs de rendement de semences furent évaluées à partir de cônes prélevés sur des ramets de clônes d'épinette noire (Picea mariana (Mill.) B.S.P.) dans un verger à graine du Nord-Ouest de l'Ontario. Aucune dormance n'a été observée chez des semences non stratifiées au froid et qui ont germé à la lumière. Des analyses de variance hiérarchisées indiquaient que les clônes et les ramets dans les clônes montrent beaucoup de variation dans le $\%$ de germination, dans le nombre de graines par cône, dans le \% de semences pleines et dans la grosseur des cônes, cette dernière étant faiblement en relation avec le nombre de graines par cône $(r=0.44)$.

\section{Introduction}

Sound black spruce (Picea mariana (Mill.) B.S.P.) seed germinate rapidly and completely under normal greenhouse and nursery conditions if extracted via recommended procedures (Safford 1974) and stored dry at $1^{\circ}$ to $5^{\circ} \mathrm{C}$. While the above handling procedures suggest that seed have no dormancy, Santon (1970) clearly demonstrated mild dormancy in seed from southeastern Ontario (Long. $77^{\circ} \mathrm{W}$, Lat. $46^{\circ} \mathrm{N}$ ) which had not been exposed to low temperature $\left(<5^{\circ} \mathrm{C}\right)$. Other studies have shown that long periods of stratification or storage in forest soil reduces germination (MacGillivray 1955 , Fraser 1976) and that viable seed will germinate at low temperatures $\left(3^{\circ}-4^{\circ} \mathrm{C}\right)$ after lengthy chilling (McArthur and

This work was completed while the senior author was an undergraduate student, School of Forestry, Lakehead University.

2Associate Professor. School of Forestry, Lakehead University, Thunder Bay, Ontario. P7B 5E1
Fraser 1963). Evidence of geographic variation in cardinal germination temperature (Fraser 1970) suggests that there may also be genetic variation in the degree of dormancy. In this study we have (1) evaluated dormancy of seed from parents in northwestern Ontario and (2) estimated genetic and environmental variance in seed and cone characteristics through use of these parents cloned in a seed orchard.

\section{Methods}

Cones from the 1981 crop only were collected on September 5,1981 , from nine clones in a grafted seed orchard (Mattawin) at Long. $90^{\circ} 05^{\prime} \mathrm{W}$, Lat. $48^{\circ}, 23^{\prime} \mathrm{N}$. Ortets for the clones are all located between Long. $88^{\circ}$ and $91^{\circ} \mathrm{W}$ at latitudes between $48^{\circ}$ and $50^{\circ} \mathrm{N}$. Orchard records indicate that all scions came from the upper crowns of ortets and were bench grafted to seedlings. The 10-ha orchard contains 18 0.2-ha blocks each of black spruce and white spruce (Picea 
glauca (Moench) Voss) and is located in a clearcut section of an even-aged jack pine (Pinus banksiana Lamb.) stand. Each block contains 12 ramets from each of 12 clones planted at $3.6 \times 3.6 \mathrm{~m}$ spacing and distributed so that ramets of the same clone are not adjacent. In the three blocks used for this test chosen ramets were planted in 1966 or 1967 and were all 4 to 5 metres in height

At least 50 cones were collected from each of three ramets per clone. None had been exposed to temperatures below $5^{\circ} \mathrm{C}$. Five randomly selected cones from each ramet were set aside for cone analysis. The remainder were extracted following procedures described by Safford (1974). Seed from each ramet was divided into two lots. Germination of one lot was evaluated immediately and the second lot was chilled on moist filter paper $3^{\circ} \mathrm{C}$ (stratified) for three weeks, then evaluated.

Three replicates of randomly selected seed from all ramets of the nine clones were incubated at a constant $20^{\circ} \mathrm{C}$. The number of seed in replicates of individual ramets varied from 10 to 50 due to variance in size of seed crops. Seed from ramets of three clones were also incubated at $10^{\circ} \mathrm{C}$ and at $30^{\circ} \mathrm{C}$. Each replicate was incubated on moist filter paper in separate $15-\mathrm{cm}$ petri dishes. Small controlled environment chambers programmed for 16 -hour day lengths were used as incubators. Numbers of germinating (radical at least $2 \mathrm{~mm}$ long) seed were recorded daily. Germination was considered complete when no additional germination occurred for 7 consecutive days; remaining ungerminated seed were sliced open under a dissecting microscope and classified as either empty (containing no embryo) or filled. This examination allowed germination percents to be based on both all seed and number of filled seed.

Nested analyses of variance using the arc sine transformations of the square root of germination percent and percent filled seed were performed using data from all replicates germinated at $20^{\circ} \mathrm{C}$. In this analysis, variance components were computed for (1) clones, (2) ramets within clones, and (3) samples within ramets. Variance associated with "ramets within clones" gives an estimate of the effects of environmental variation within the orchard and/or environmental preconditioning of ramets. An additional analysis of variance was performed using data from seed of the three clones germinated at $10^{\circ}, 20^{\circ}$, and $30^{\circ} \mathrm{C}$. Effect of statification was evaluated in both analyses.

Volumes of five freshly collected cones per ramet were determined by water displacement. These cones were then extracted and the number of seed per cone determined. Each cone was then dissected to remove any seed not obtained by extraction. A nested analysis of variance was performed on cone volume data and number of seeds per cone.

\section{Results}

The average germination in the study was 40 percent for all seed and 94 percent for filled seed. Neither stratification nor temperature significantly influenced final germination percent. Germination speed, measured by number of days to reach 90 percent of final germination, was significantly slower ( 17 days) at $10^{\circ} \mathrm{C}$ than at $20^{\circ} \mathrm{C}\left(5\right.$ days) and $30^{\circ} \mathrm{C}$ ( 4 days) Stratified seed completed germination 1 to 2 days before unstratified seed, probably due to the fact that they had completed imbibition at the beginning of incubation while unstratified seed began imbibition on the first day of incubation.

There was significant variation among clones and ramets within clones in germination percent based on all seed. Clone means ranged from 23 to 56 percent at $20^{\circ} \mathrm{C}$ (Table 1). The analysis of variance of data from seed incubated at $20^{\circ} \mathrm{C}$ indicated that clones and ramets within clones each accounted for around 20 percent of variance in both germination and percent of seed which were filled (Table 2). Thus clone and ramet variance in germination percent is largely a function of percent filled seed, not germination potential of filled seed. The relatively large amount of variance within ramets is at least partly due to the small samples dictated by limited seed from some ramets.

Wide variation in cone volume and number of seed per cone (Table 1) was also related to both clones and ramets within clones, with the latter source of variance especially substantial (Table 2). While there was a statistically significant $(p<.05)$ positive correlation between cone volume and number of seed per cone, it had a coefficient ( $r$ ) of only .44 Mean number of filled seed per cone was 15 for the total sample, and clone means (computed using percent of filled seed and mean number of seed per cone) ranged from 5 to 24

\section{Discussion}

Our data demonstrate that current year's seed collected before natural chilling from trees at Long. $90^{\circ}-91^{\circ} \mathrm{W}$ and Lat. $48^{\circ}-49^{\circ} \mathrm{N}$ exhibit no dormancy under a range of incubation temperatures and a 16-hour photo-period. The only equivalent published study is that of Santon (1970) in which seed from around Long. $77^{\circ} \mathrm{W}$ and Lat. $46^{\circ} \mathrm{N}$ responded to stratification. Thus the limited evidence to date suggests that there may be geographical variation in the degree of dormancy at fall collection. However, since seed are usually dispersed after some chilling and germination of cold-stored seed is commonly high, this variation in chilling is probably of little practical or ecological significance.

Of more interest is the variance in seed quality associated with both clones and ramets within clones in this young seed orchard. O'Reilly et al. (1982) have already observed some within-clone variation in cone production in this orchard that is

\begin{tabular}{|c|c|c|c|c|c|c|c|c|c|c|}
\hline \multirow[t]{2}{*}{$\begin{array}{l}\text { Clone } \\
\text { No. }\end{array}$} & \multicolumn{4}{|c|}{$\begin{array}{l}\text { Germination percent at } 20^{\circ} \mathrm{C} \text { based on: } \\
\text { All seed }\end{array}$} & \multicolumn{2}{|c|}{$\begin{array}{l}\text { Percent of seed } \\
\text { filled }\end{array}$} & \multicolumn{2}{|c|}{$\begin{array}{c}\text { Cone Volume } \\
\mathrm{cm}^{3}\end{array}$} & \multicolumn{2}{|c|}{$\begin{array}{l}\text { Number of seed } \\
\text { per cone }\end{array}$} \\
\hline & Mean & Ramet range & Mean & Ramet range & Mean & Ramet range & Mean & Ramet range & Mean & Ramet range \\
\hline 284 & 40 & $31-52$ & 90 & $88-94$ & 45 & $33-57$ & 1.6 & $1.1-2.6$ & 25 & $12-40$ \\
\hline 285 & 56 & $41-70$ & 96 & $95-97$ & 58 & $43-72$ & 2.4 & $2.0-2.9$ & 26 & $23-31$ \\
\hline 290 & 35 & $24-44$ & 95 & $89-100$ & 37 & $26-47$ & 1.4 & $1.1-1,8$ & 14 & $15-33$ \\
\hline 291 & 34 & $29-38$ & 86 & $83-90$ & 40 & $33-47$ & 2.5 & $2.3-2.6$ & 34 & $24-42$ \\
\hline 303 & 23 & $18-27$ & 100 & & 23 & $17-27$ & 2.3 & $2.0-2.6$ & 49 & $38-61$ \\
\hline 374 & 40 & $33-54$ & 96 & $93-98$ & 43 & $36-50$ & 1.8 & $1.1-2.5$ & 43 & $36-48$ \\
\hline 383 & 53 & $37-62$ & 95 & $92-100$ & 56 & $38-68$ & 2.2 & $1.9-2.4$ & 30 & $22-40$ \\
\hline 386 & 53 & $32-67$ & 88 & $76-100$ & 59 & $42-68$ & 1.9 & $1.7-2.1$ & 32 & $18-48$ \\
\hline 492 & 51 & $38-59$ & 98 & $96-99$ & 52 & $40-59$ & 2.0 & $1.6-2.5$ & 46 & $40-51$ \\
\hline Mean & 43 & & 94 & & 46 & & 2.0 & & 33 & \\
\hline
\end{tabular}


Table 2. Components of variance in cone and seed characteristics in a black spruce seed orchard.

\begin{tabular}{|c|c|c|c|c|}
\hline \multirow[t]{2}{*}{$\begin{array}{l}\text { Source of } \\
\text { variation }\end{array}$} & \multicolumn{4}{|c|}{$\begin{array}{l}\text { Variance components expressed as } \\
\text { percent of total variance }\end{array}$} \\
\hline & $\begin{array}{l}\text { Percent } \\
\text { germination } \\
\text { at } 20^{\circ} \mathrm{C}\end{array}$ & $\begin{array}{l}\text { Percent } \\
\text { filled } \\
\text { seed }\end{array}$ & $\begin{array}{l}\text { Cone } \\
\text { volume }\end{array}$ & $\begin{array}{c}\text { Number } \\
\text { seed per } \\
\text { cone }\end{array}$ \\
\hline $\begin{array}{l}\text { Clones } \\
\text { Ramets within }\end{array}$ & 21 & 20 & 20 & 26 \\
\hline clones & 17 & 22 & 32 & 42 \\
\hline Within ramets & 62 & 56 & 48 & 31 \\
\hline
\end{tabular}

not related to ramet size. Particularly noteworthy in our study was the relatively high level of variance in cone size among ramets of uniform origin and history. Broad-sense heritability, a measure of genetic control, was not estimated for cone and seed characteristics due to the small sample size ( 9 clones). However, it is clear that if the relationships we observed are typical of larger populations, the broad-sense heritability for cone size, seed per cone, and filled seed percent may be low. This may have important implications for seed orchard management since selection for fecundity will not be very effective given this relatively low level of genetic control. Because of our limited sample size, these conclusions are tentative, and the study should be followed by broader examination of this orchard as it ages and similar evaluation of other black spruce clonal orchards.

McPherson et al. (1982) have shown that in a similar orchard (Long. $86^{\circ} 30^{\prime}$; Lat. $49^{\circ} 47^{\prime}$ ) mean number of sound seed per cone varies widely from year to year and averages only about 11 , a figure slightly lower than our observed 1981 value (15). The generally low filled seed percent in these young orchards may be partly due to a pollen isolation barrier and/or limited male strobili production in the orchards. O'Reilly et al. (1982) noted that in 1979, clones from the blocks used in our test produced from 150 to 4550 male strobili per ramet, with a few clones contributing most of the pollen. Maximum pollen dispersal and female receptivity coincided. Thus while there was probably a substantial orchard pollen cloud in 1981, no direct measurements of pollen abundance and periodicity have been made. Before orchard management recommendations for improving yield can be made, seed yield analysis should be supplemented by pollen sampling and observations of pollen dispersal patterns for individual parents.

\section{References}

Fraser, J.W.1970. Cardinal temperatures for germination of six provenances of black spruce seed. Can. For. Ser. Petawawa For. Exp. Sta. Inf. Rep. PS-XX-23.12 p

Fraser, J.W. 1976. Viability of black spruce in or on a boreal forest seedbed. For.Chron. 52(5) 299-231

MacGillivray, H.G. 1955. Germination of spruce and fir seeds following different stratification periods. For. Chron. 31:365

McArthur, J.D. and J.D. Fraser. 1963. Low temperature germination of some eastern Canadian tree seed. For. Chron. 39:478-479.

McPherson, J.A., E.K. Morgenstern and B.S.P. Wang. 1982. Seed production in grafted clonal orchards at Longlac. Ontario. For. Chron. 58:31-34.

O'Reilly, C., W.H. Parker and J.F. Barker. 1982. Effect of pollination period and strobili number on random mating in a clonal seed orchard of Picea mariana. Silvae Genetica. 31(2-3)90-94.

Safford, L.O.1974. Picea A. Dietr. Spruce. In Seed of Woody Plants in the United States. USDA Forest Service. Agri. Handbook No. 450. p.587-597

Santon, J. 1970. Effects of stratification on germination of freshly harvested seed of several spruce and pine species in eastern Canada. Can. For. Serv. Petawawa For. Exp. Sta. Info. Rep. PS-X-17, 22p.

\section{Acknowledgements}

The authors are grateful to G.H. Kokocinski and R.M. Rauter of the Ontario Ministry of Natural Resources for making available the seed used in this study.

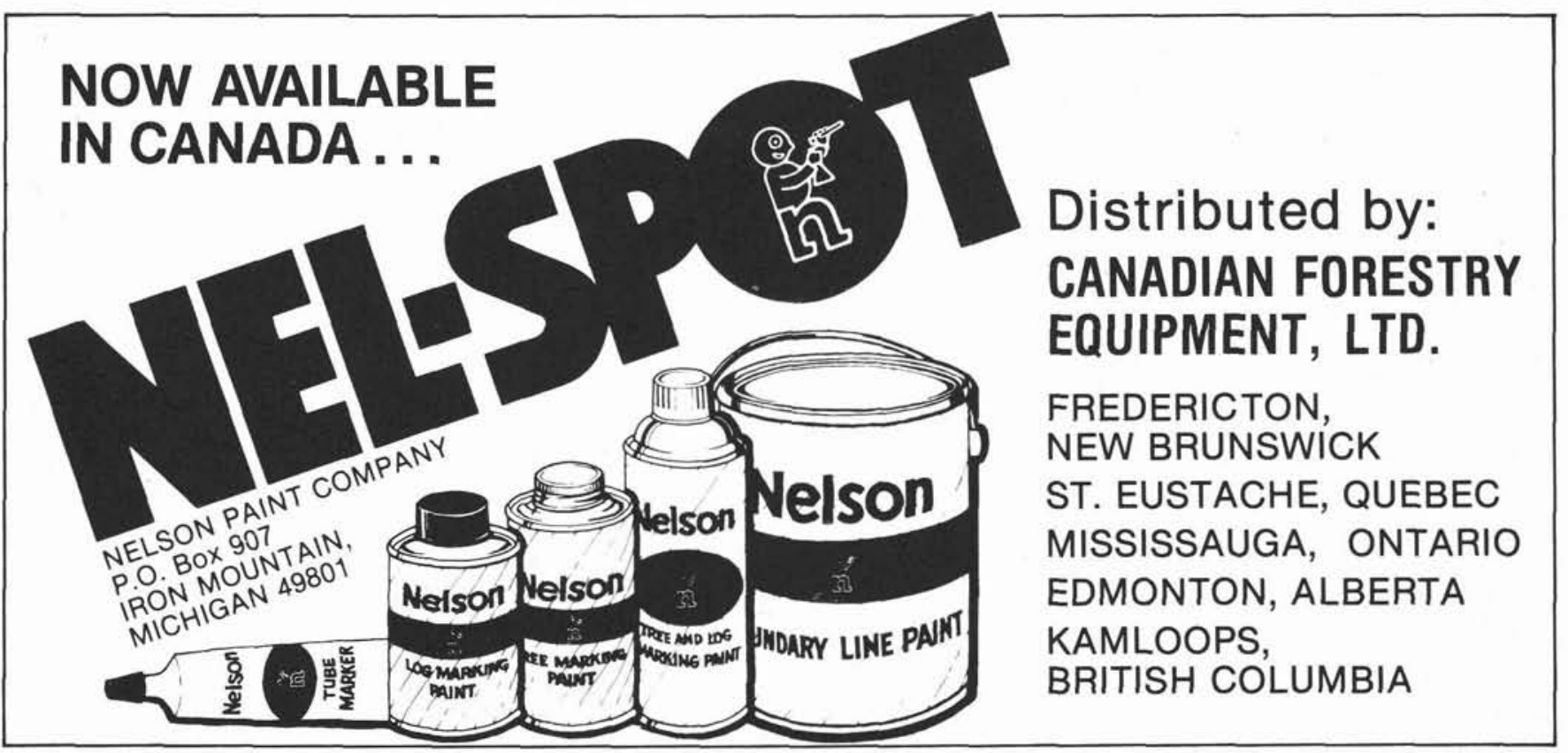

